\title{
Legal Aspects of Book Censorship And Their Relationships to Academic Libraries
}

\author{
BY TERRENCE J. MURPHY
}

Censorship of expression is one of the perennially unfinished businesses of our society. It seems safe to say that the last word on this subject will never be said.

Anthropologist Margaret Mead has stated that every known human society has some form of explicit censorship relating to sex. ${ }^{1}$ This arises from society's twin needs of controlling sex and of cherishing it. The cultural, intellectual, legal, and governmental patterns and climates in which these two needs are expressed are constantly changing. Consequently there is no static solution to the problem of censorship. There is no pat solution, no facile answer, to the question of censorship.

At the beginning it seems proper to delimit the topic. Censorship exists in three areas: the libelous and slanderous, the subversive, and the obscene. I take it that the first type, that is, libelous and slanderous, is not a major problem to librarians. Subversive material, mostly Communistic propaganda, when it constitutes the advocacy of the violent overthrow of government as a duty, is prohibited by federal law. Obscenity has been proscribed by numerous federal and state laws. In addition there are international agreements outlawing obscenity. Almost every civilized country has some restrictive laws on this subject. Obscenity is defined in this country as material whose dominant theme appeals to the prurient or lustful interests of the average adult when judged by contemporary community standards. It is this

\footnotetext{
1 Margaret Mead, "Sex and Censorship in Con temporary Society" in New World Writings (New York: The American Library of World Literature, 1953), p. 7.
}

Father Murphy is Assistant Professor of Political Science at the College of St. Thomas, St. Paul, Minnesota. He was recipient of the Hill Foundation grants for research in the area of civil liberties in 1960 and 1961.

last type of censorable material that I wish to consider, since I presume it presents the most vexing problems and situations for librarians.

The definition of obscenity and the standards to be employed in applying the definition as they have been interpreted by the United States Supreme Court are minimal. It can be said generally that they reach only the most vile kind of pornography. The courts have shown a decided unwillingness to restrict anything that can claim social usefulness, and literary or artistic value. The post office department makes about four hundred arrests and secures almost as many convictions annually for violations of the postal obscenity statutes. These are for material which on its face is immediately recognized as hard core pornography. Rarely are convictions appealed, so evident is the guilt. The federal government has had obscenity statutes for almost one hundred and twenty years and yet, as Judge Bryan pointed out in the Chatterly case, only two works of notable literary merit have come before the federal courts. ${ }^{2}$ And in both these instances the courts have allowed them to circulate. It would seem then that legal censorship would rarely be a problem in the life of a librarian. In

${ }^{2}$ Grove Press vs Christenberry, 175 F Supp. 488 (1959), 498 . 
fact, when it is understood what really is the character of the material caught in the censor's net and when at the same time the most strident cries of outrage against the enforcement of the obscenity laws are heard from some articulate circles, questions arise as to how well informed on the factual situation are the protesters. Emotion is a poor substitute for factual knowledge and careful reasoning.

To suggest that censorship is hardly a major daily problem for the rank and file librarian is not to suggest that there are not difficult problems in book selection and in library policies to be met frequently. Certain facets of such problems can be identified. The identification of various considerations may aid in forming a balanced judgment on library questions. It seems to me to be particularly important to emphasize that there are a number of considerations, sometimes conflicting considerations, that go into decision-making in this area. The simple solution of raising the liberties of the press to absolutes that override every other consideration may deliver the librarian from the tough intellectual chore of identifying and balancing interests, but its simplicity ought not to be allowed to cover over its one-sidedness and often its unrealistic character.

Our society accords freedom a high place, even a preferred place, in its scale of values. This it does rightly, for the safeguarding, or rather the constant enlarging, of freedom for every man is necessary for the development of mature, self-reliant, responsible, intelligent, and free citizens composing a free society. But freedom is not the only goal of our society. It is one among several. The goals set forth in the preamble to our constitution have never been rejected by the American people: "We the People of the United States, in order to form a more perfect Union, establish justice, insure domestic tranquillity, provide for the common defense, promote the general welfare, and secure the bless- ing of liberty to ourselves and our posterity, do ordain and establish this Constitution ..."

Even though freedom is not the only cherished value in our society, it is an essential one, and for the librarian it ought to be a fundamental consideration in the formulation of library policies and decisions. A corollary of this is that in case of doubt the benefit of the doubt should be given to liberty. This is particularly true when the decision is made by an individual rather than a group. There is a wide range of human sensibilities, interests, and capacity to remain unaffected by the portrayal of evil. Gauging the effects of salacious material on potential readers who vary greatly in temperament, education, and moral training is a difficult-some say an impossible-task. One's own reactions are poor indicators. And thus it would seem to be a good working rule to favor liberty. Moreover the librarian must allow room for the reader to exercise his own personal responsibility in the books he reads.

American society not only prizes freedom dearly; it also regards justice as one of its goals. This value, too, should be weighed in the librarian's scale. It is one of the factors in the complex equation of library policy making. Libraries have a clientele, or a public, to whom they owe certain obligations. Perhaps it would be clearer to say they have a number of differentiated publics which they serve and to which they owe obligations. These will vary depending on the type of library, whether public or private, whether established for certain specified purposes, whether the likely reader is a child, an adult, or a highly professional researcher.

The young and immature undoubtedly represent the greatest problem in regard to lascivious material. Here it would seem that there is a particular obligation to be sensitive to the rights of parents. Theirs is the primary right and obligation to direct the upbringing 
of their children. The natural dependency of the child on the parent is evidence of this natural right. That it is also a constitutional right the United States Supreme Court has affirmed in the Pierce case and again more recently in the Barnette decision. In recognition of these rights there is increasing interest in, and discussion of, the feasibility of establishing systems of classifying material according to age groups. This discussion centers chiefly around the classification of motion pictures. Great Britain, for example, uses a system of classification of movies. It would seem that there would be considerable merit in classifying reading material according to age groups or readers.

The problem of protecting parental rights can hardly be shrugged off with the remark that it is up to the parents to watch their children's reading fare. In our society youngsters spend so much time out of the home and away from their parents and in environments which are beyond the control of parents that parents in practice cannot exercise their rights to guide the development of their children without the cooperation of many agencies in society. Moreover, students of youthful behavior seem generally agreed that a basic factor in the increase of juvenile delinquency and aberrant moral conduct is the breakdown of traditional home influences and parental control. Consequently it is precisely the youngsters who need most the guidance of their parents in forming their reading habits who are least likely to get such guidance.

The responsibility of the librarian is increased where the library is part of a boarder-student school in which the relationship of the school to the boarder student is somewhat in the nature of a "loco parentis" relationship. It is not uncommon to find in church-related educational institutions that parents have such implicit confidence in the school administrators that they unfortunately abdicate their responsibilities in the as- sumption that every book and magazine bought by the library is beyond criticism.

Parents are by no means the only public of a library. There are taxpayers and donors whose monies are taken for the intellectual improvement of the community be it an academic community or a community composed of the generality of citizens. Justice requires that the money be spent on those materials that are of social and intellectual value.

Our land is dotted with libraries because they have traditionally been regarded as necessary institutions for the cultural and intellectual improvement of our people. Second only to church and school, Americans look to their libraries as sources of intellectual growth. Libraries have a commitment in justice to the intellectual life. Since library budgets are limited and since the amount of printed material appears to be almost limitless, the wise use of funds for material of intellectual value would seem to leave nothing for the purchase of pernicious trash.

Libraries that are part of private educational institutions have a different or more specialized public to which they are responsible than do tax-supported libraries. Their revenue comes from nonpublic sources and frequently the contributor has in mind certain values to the furtherance of which he intends his contribution. These purposes should be respected. The library should be directed toward the same goals as the school itself. However, every educational institution worthy of the name, whatever its affiliation, is dedicated to intellectual excellence. And library holdings must be of such a nature and universality as to assist the student in attaining the best possible education.

The suggestion made in this presentation is that there are many elements that must be taken into consideration, weighed, and balanced. Often attempts must be made to reconcile conflicting interests and values in the determination 
of library policies. Certain general areas of these interests and values have been indicated. This formula for decision making, namely the weighing of interests and values, may not be as simple, as easy, and as clear-cut as the freedom-isan-absolute approach. But I submit that it is truer to the spirit and traditions of our land. The constitution which has molded and directed the destiny of the American people is itself a document characterized by balance and room for many values. The Supreme Court, which is the official interpreter of that monumental document, has affirmed throughout its history that none of the constitutional freedoms and guarantees can be taken in isolation, in disregard of other claims and raised to an absolute. The majority of the justices who dominate the Supreme Court today adhere, as did their predecessors, to what has come to be known in the phrase of Roscoe Pound as the "balancing of interest" doctrine, despite the protests of an articulate mi- nority. It is this judicial formula of balancing interests that I propose to you for the making of library policies.

No suggestion is made that this formula will shield the librarian from the pressures of the axe-grinders. Courage will ever be demanded. Confidence in the intellectual integrity of readers will always be needed. There will still be extremists of the right and of the left; there will be the puritanical and the carnal-minded; there will be those who would turn a library into a propaganda vehicle rather than an intellectual storehouse; those who would restrict a reading list to what is fit for a child and those who would stock a library as if a child would never set foot in it. But balanced, carefully-considered judgments can give the librarian confidence in his policies and a conviction that he is serving all segments of his constituency in a manner consistent with the deepest and finest contradictions of American society.

\section{West German National Library}

At the end of World War II the great $3,000,000$ volume collection of the former Prussian State Library lay divided: about 1,300,000 volumes were in the familiar building on Unter den Linden in East Berlin where they have remained; approximately $1,700,000$ volumes were in the old West German university town of Marburg. Many of the most valuable manuscripts (about 18,000) and incunabula (about 2,300 ) are stored in a vault in the University Library at Tübingen. The collection at Marburg, now called the Westdeutsche Bibliothek, and increased to $2,000,000$ volumes, is miserably housed and only partially cataloged, the catalogs of the Prussian State Library having for the most part remained in East Berlin. Ever since the end of the war, discussions, up to now inconclusive, have taken place concerning new, permanent housing for the Westdeutsche Bibliothek.

According to the latest issue of Biblos (Vol. 11, No. 3, 1962, pp. 174-175) a decision has finally been reached. A national library for West Germany will be built on the Kemperplatz in West Berlin. Plans have been drawn up by Director of Buildings, Werner Düttmann, for a building with a two hundred foot high (stack?) tower to house $8,000,000$ volumes. The building is expected to cost in the neighborhood of $\$ 12,500,000$ which, in view of German building costs, would be the equivalent of about a $\$ 25,000,000$ building in the United States.-J. Periam Danton in $C U$ News, Vol. 17, No. 25. 